\title{
Mini Review: Immunohistochemistry Using EGFR-Mutant Specific Antibodies in Non-Small Cell Lung Carcinoma: Accuracy and Reliability Rania Gaber ${ }^{1,2,3}$, Torsten Goldmann ${ }^{1,3 *}$ \\ 'Pathology of the University of Lübeck and the Research Center Borstel, Site Borstel, Clinical and Experimental Pathology, Borstel, Germany \\ ${ }^{2}$ Department of Pathology, Faculty of Medicine, Alexandria University, Alexaandria, Egypt \\ ${ }^{3}$ Airway Research Center North (ARCN), Member of the German Center for Lung Research, Germany
}

Article Info

\section{Article Notes}

Received: June 18, 2018

Accepted: August 23, 2018

\section{*Correspondence:}

Dr. Prof. Dr. rer. nat. Torsten Goldmann, Principal Investigator, Pathology of the University of Lübeck and the Research Center Borstel, Site Borstel, Clinical and Experimental Pathology, Borstel, Airway Research Center North (ARCN), German Center for Lung Research, Borstel, Germany; tgoldmann@fz-borstel.de.

(c) $2018 \mathrm{Gaber} R$. This article is distributed under the terms of the Creative Commons Attribution 4.0 International License.

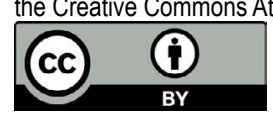

Abstract

Epidermal growth factor receptor (EGFR) is a predictive biomarker in many solid cancers including non-small cell lung carcinoma (NSCLC). Patients' responsiveness to therapy is based on the prior determination of EGFR status. Many techniques were used to detect the potential predictive biomarker and considered as gold standards based on molecular genetic techniques as direct sequencing and polymerase chain reaction (PCR). Immunohistochemistry (IHC) using EGFR mutation-specific antibodies were generated as an alternative simple tool to identify EGFR status and its response to tyrosine kinase inhibitors (TKIs). EGFR gene copy number and wild-type EGFR are other parameters which determine the response to TKIs. The aim of this mini-review is to analyze the studies which investigated the IHC EGFR mutation-specific antibodies, in lung adenocarcinoma (ADC), to determine its accuracy and reliability as a preselection tool for candidate patients for TKIs therapy as well as the interplay with other EGFR biomarkers which are EGFR gene copy number and the wildtype EGFR in lung NSCLC. The later determine the response to TKIs and their detection methodology is standardized making them good candidates for comparison with the EGFR-mutation.

\section{Introduction}

Epidermal growth factor receptor (EGFR) is an important target for individualized therapy in non-small cell lung carcinoma (NSCLC) including monoclonal antibodies and tyrosine kinase inhibitors (TKIs) ${ }^{1}$. EGFR activation depends on EGFR mutation, increased gene copy number and EGFR overexpression ${ }^{2}$. Patients selection for this kind of targeted therapy is guided by the identification of EGFR receptors mutation, gene copy number increase and level of protein expression. The association between the EGFR mutation, overexpression and EGFR increased copy number was reported ${ }^{3-5}$. Mutated EGFR is a target for therapy using TKIs gefitinib, erlotinib and afatinib ${ }^{6}$, increased gene copy number is associated with better response to TKIs $^{4,7}$.

The epidermal growth factor receptor (EGFR) is an important marker for predicting responses to TKIs in NSCLC. IHC is a technique routinely applied in medical laboratories because of its convenience and simplicity. The aim of this mini-review is to discuss the role of IHC as a useful and sensitive prescreening method for EGFR mutation detection compared to other available methods. We also discuss the diagnostic significance of EGFR mutations, overexpression and increased gene copy number in NSCLC. 


\section{EGFR Mutation in NSCLC}

EGFR somatic mutations in the tyrosine kinase domain are analyzed in exons 18-21 of EGFR to predict clinical responses to gefitinib and erlotinib ${ }^{6,8,9}$. The two most common EGFR mutations are the exon 19 deletions (including E746-A750) which accounts for $45 \%$ of all EGFR mutations and the exon 21-point mutation L858R which accounts for $39 \%$ of exon 21 mutation. These two mutations together form $90 \%$ of EGFR mutation in NSCLC tumors ${ }^{10,11}$.

EGFR mutation was commonly detected by molecular techniques including direct sequencing of the polymerase chain reaction (PCR)-amplified exon sequence ${ }^{12}$. Another more sensitive method is the amplification refractory mutation system (ARMS) combined with the scorpion method $^{13,14}$. ARMS is based on the detection of single base or small deletion using specific PCR, the use of the scorpion probe allows increased specificity and fast amplicon detection ${ }^{15,16}$.

\section{EGFR Mutation by Molecular Genetic Techniques}

Molecular genetic techniques are considered the gold standard tests for EGFR mutation detection. The EGFR-QRG-PCR (Qiagen) using ARMS with scorpions and the Cobas EGFR mutation test -v2 (real-time PCR) are molecular genetic tests approved by the Food and Drug Administration (FDA) ${ }^{17,18}$.

Many studies have demonstrated the limitations of the adoption of direct DNA sequencing of PCR-amplified genomic DNA as the main clinical test ${ }^{19,20}$. Penzel et al showed from multi-institutional studies that many mutations were missing by direct DNA sequencing of PCR amplified genomic DNA ${ }^{19}$. Ellison et al showed that the use of direct DNA sequencing is a low sensitivity, time consuming technique with lack of standardization ${ }^{20}$. Other limitations of this technique include the high cost, and the technical difficulties like prolonged procedure, impurity of the DNA and the variability of the number of the tumor cells in the specimen, as well as the tumor heterogeneity of cells carrying the mutant gene, imbalanced PCR amplification and the presence of contaminated wild-type allele in the amplicons $^{2,21}$.

Other molecular genetic techniques, like mass spectrometry were developed to overcome the limitations of DNA sequencing but still show some issues as their high cost, and technical difficulties making them hard to be routinely used as EGFR mutation-selection tools ${ }^{2,11}$.

\section{EGFR-Mutation-Specific Antibodies and IHC}

IHC, on the other hand, has both advantages and limitations. The advantages include that it is a robust, routinely used technique in laboratories worldwide, whether for diagnostics or for prediction of responses to therapy ${ }^{11}$.
In 2009, Yu J et al developed two IHC mutation-specific antibodies to detect the 2 most common EGFR mutations: The E746_A750 axon 19 deletion and L858R axon 21-point mutation. The 2 antibodies are the rabbit mAb (clone 43B2) highly specific for the point mutation L858R on exon 21 and the rabbit mAb (clone 6B6) specific for E746_A750 deletion on exon 19 (Cell Signaling Technology, Danvers, MA, USA), they detect these mutations in western blot, immunofluorescence, and IHC21. Other 2 antibodies used to detect the same mutations are rabbit monoclonal antibody clone SP111 to detect delE746-A750 and rabbit monoclonal antibody clone SP125 to detect L858R pointmutation on exon 21 (Ventana Medical Systems, Tucson, $\mathrm{AZ}, \mathrm{USA})^{22,23}$.

While IHC assays offer advantages in clinical practice, it is important to employ standardized reagents, procedures and scoring system. In particular, it is critical to use highly specific antibodies for the mutations of interest. The antibodies used and the experimental conditions applied, including for antigen retrieval, should be constant across the studies. These parameters were standardized in most of the studies investigating the EGFR mutation-specific antibodies in lung $\mathrm{ADC}^{21,23,25-33}$.

The scoring system is an important factor influencing the results of IHC and thereby potentially also the choice of targeted therapy and the clinical outcome. Therefore, a standardized IHC scoring system should be considered. $\mathrm{Yu} \mathrm{J}$ et al, in their study of IHC EGFR mutation-specific antibodies generation, used a specific scoring system based on the intensity and the percentage of the positive tumor cells ${ }^{11}$. Yu J ET AL scoring system considered the cells as positive if $>10 \%$, and negative if no staining. Regarding the intensity, it was scored as weak, moderate, and strong ${ }^{21}$.

\section{Application of IHC for the Detection of EGFR in} NSCLC

The performance of the four EGFR mutation-specific antibodies mentioned above and available from Cell Signaling Technology and Ventana in IHC of NSCLC has been investigated in several studies.

Comparison between EGFR mutation detected by IHC and different gold standard techniques including direct sequencing, PCR, peptide nucleic acid-locked nucleic acid polymerase chain reaction clamp method, (a sensitive PCR method used to hinder the amplification of the wildtype allele allowing the detection of the mutation-specific allele $^{24}$, fragment analysis and mass spectrometry was performed. Using statistical analysis, EGFR mutationspecific antibodies showed high specificity and sensitivity with high concordance level compared to the molecular gold standards techniques ${ }^{23,25-33}$.

Brevet and colleagues applied the EGFR mutationspecific antibodies 43B2 and 6B6 for IHC in 218 cases of 
lung ADC. The results of IHC staining were compared to sequencing for EGFR exon 19 deletion, Mass spectrometry for exon 21 mutation. The results showed sensitivity of $84.6 \%$ and specificity of $98.9 \%$ for $6 \mathrm{~B} 6$ antibody and sensitivity $95.2 \%$ and specificity $98.8 \%$ for $43 \mathrm{~B} 2$ antibody (25). Simonetti $S$ et al studied 78 cases of stage IV NSCLC cell lines and found high correlation between IHC and the molecular technique using fragment analysis for exon 19 and Taqman assay for exon $21^{26}$.

Furthermore, Kawahara et al investigated 60 ADC cell lines by IHC. The sensitivity of mutation detection by IHC compared to DNA sequencing data was $79 \%$ for $6 \mathrm{~B} 6$ and $83 \%$ for the $43 \mathrm{~B} 2$ antibody. The sensitivity and specificity between IHC 43B2 and 6B6 EGFR-mutation-specific antibodies (Cell Signaling Technology, Danvers, MA, USA) and DNA sequencing was also high in Kim CH ET AL using SP111/ SP125 (Ventana Medical Systems, Tucson, AZ, USA) and DNA sequencing.

Nakamura et al study stained 20 cases of lung ADC with the same Cell Signaling Technology EGFR-mutation antibodies by IHC and compared the results to peptide nucleic acid-locked nucleic acid polymerase chain reaction clamp method and DNA sequencing with $90 \%$ sensitivity and $100 \%$ specificity for the IHC results ${ }^{28}$.

Jiang G et al also compared IHC staining using the same clones on 399 ADC tumors and compared the results to Taqman PCR with a specificity and positive predictive value (PPV) of $100 \%$ with score $3+$, PPV $93 \%$ with score 0 , and unreliable results with scores $1+$ and $2+^{30}$.

Similarly, Jain D et al compared the IHC results of EGFRmutation-specific antibodies on 2016 cases of lung ADC, to high resolution melting analysis, DNA sequencing and fragment analysis, and concluded a concordance rate of $85.7 \%$ between the IHC and the molecular technique.

Allo $\mathrm{G}$ et al compared the results from IHC using the four mutation-specific antibodies to results from mass spectrometry, fragment analysis and direct PCR sequencing platforms in 247 ADC samples. The results were76\% sensitivity and $73 \%$ PPV for SP125 compared to $62 \%$ sensitivity and $87 \%$ PPV for 43B2 while the sensitivity and the PPV were $83 \%$ and $94 \%$ for SP111 compared to $89 \%$ and $76 \%$ for $6 \mathrm{~B} 6$ respectively ${ }^{31}$.

Bondgaard et al study compared EGFR mutations by RT-PCR to IHC using (43B2/6B6 Cell Signaling Technology, Danvers, MA, USA) on 210 NSCLC specimens. The authors concluded a high specificity of IHC compared to the sensitivity mainly for exon 19 (34). The same result was reported by Seo et al study on 240 resected lung ADC using SP111/ SP125 (Ventana Medical Systems, Tucson, AZ, USA). The authors reported high specificity and low sensitivity mainly in exon 19 mutation detection except for E746_A750 mutation ${ }^{35}$.
Yoshida $\mathrm{M}$ et al have also investigated the interpretation of IHC EGFR mutated specific antibodies in both surgical and cytological specimens compared to the molecular technique. Using clones SP111 and SP125 (Ventana Medical Systems, Tucson, AZ, USA), IHC and Immunocytochemistry demonstrated sensitivities of $100 \%$ and $33.3 \%$ and specificities of $100 \%$ and $100 \%$ respectively ${ }^{22}$. Table 1 shows some of the published articles investigating the EGFR-mutation-specific antibodies and the gold standard techniques in lung ADC.

\section{EGFR Mutation, Gene Copy Number and Protein Overexpression}

The significance of EGFR gene copy number and EGFR protein expression as predictive biomarkers was demonstrated by different studies ${ }^{36,37}$. EGFR gene copy gain is considered a biomarker for TKI responsiveness ${ }^{7,38}$ EGFR gene copy number is detected by Fluorescence in situ hybridization (FISH). The Colorado scoring system is the most commonly used to interpret EGFR gene copy number ${ }^{38}$.

Many studies have investigated the assessment of the reproducibility of EGFR gene copy number analysis using the FISH technique. Of these studies, Zlobec et al performed FISH analysis on 170 histological and 153 cytological specimens with a high inter-observer agreement using the Colorado scoring system ${ }^{39}$.

Our group studied 216 cases of lung ADC. The presence of EGFR mutations was analyzed using IHC with the EGFRmutation specific antibody clones 43B2 and 6B6, gene copy numbers was investigated by FISH using the Colorado scoring system, and to study EGFR overexpression we used IHC with an antibody specific for wild-type EGFR (clone 31G7, Diagnostic BioSystems, Netherlands). We found a positive association between the presence of EGFR mutations and both EGFR overexpression and increased EGFR gene copy numbers ${ }^{33}$ (Figure 1). We also investigated the relation between gene copy number using FISH and wild-type EGFR overexpression and EGFR gene copy

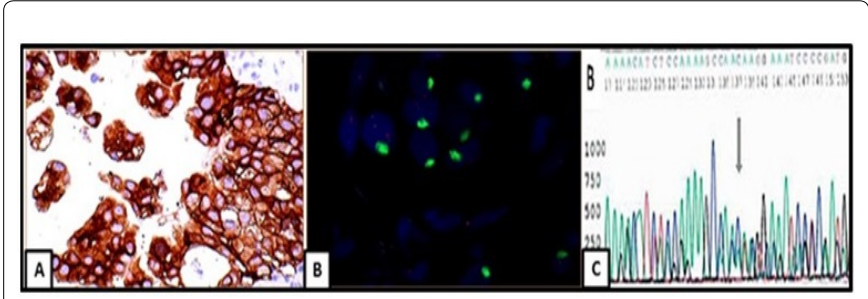

Figure 1: (A) IHC of an ADC case showing EGFR mutation for exon 19 deletion (E746-750) using mutation specific antibody clone 6B6 (Cell Signaling Technology, Danvers, MA, USA), (B) FISH analysis showing high amplification and (C) DNA sequencing of exon 19 deletion (E746-750) (original magnification, $\times 400$ ). ADC; Adenocarcinoma, EGFR; Epidermal growth factor receptor, IHC; Immunohistochemistry ${ }^{33}$. 
Table 1: Review of literature of some of the articles investigating IHC EGFR mutation specific antibodies in lung adenocarcinoma

\begin{tabular}{|c|c|c|c|c|c|}
\hline $\begin{array}{l}\text { Patient } \\
\text { information }\end{array}$ & $\begin{array}{l}\text { Antibody information and } \\
\text { methods }\end{array}$ & Scoring system & Gold Standard & Conclusions & References \\
\hline 218 ADC & $\begin{array}{c}\text { 6B6 and 43B2 } \\
\text { (Cell Signaling Technology, } \\
\text { Danvers, MA, USA) } \\
\text { Concentration: 1:100 } \\
1 \text { mmol/L EDTA (pH 9.0) } \\
\text { target retrieval solution } \\
\text { (DakoCytomation) }\end{array}$ & $\begin{array}{l}0: \text { no staining, } 1+; \\
\text { weak, } 2+; \text { moderate, } \\
3+\text {; strong in }>10 \% \text { of } \\
\text { cancer cells. }\end{array}$ & $\begin{array}{l}\text { Sequencing for EGFR } \\
\text { exon } 19 \text { deletion, Mass } \\
\text { spectrometry for exon } \\
21 \text { mutation }\end{array}$ & $\begin{array}{l}\text { 6B6 antibody: } \\
\text { Sensitivity of } 84.6 \% \\
\text { and specificity } \\
\text { of } 98.9 \% .43 \mathrm{~B} 2: \\
\text { Sensitivity } 95.2 \% \text { and } \\
\text { specificity } 98.8 \%\end{array}$ & $\begin{array}{l}\text { Brevet } \mathrm{M} \text { et al } \\
\mathrm{JMD} / 2010^{25}\end{array}$ \\
\hline $\begin{array}{l}78 \text { stage IV } \\
\text { NSCLC and } \\
5 \text { NSCLC cell } \\
\text { lines }\end{array}$ & $\begin{array}{c}6 \mathrm{~B} 6 \text { and 43B2 } \\
\text { (Cell Signaling Technology, } \\
\text { Danvers, MA, USA) } \\
\text { Concentration: } 1: 100 \\
1 \text { mmol/L EDTA (pH 9.0) } \\
\text { target retrieval solution } \\
\text { (DakoCytomation) }\end{array}$ & $\begin{array}{c}0: \text { no staining, } 1+; \\
\text { weak, } 2+; \text { moderate, } \\
3+\text {; strong in }>10 \% \text { of } \\
\text { cancer cells. }\end{array}$ & $\begin{array}{l}\text { Fragment analysis for } \\
\text { exon } 19 \text { and Taqman } \\
\text { assay for exon } 21 \text {. }\end{array}$ & $\begin{array}{l}\text { 6B6 antibody: Positive } \\
\text { patients with a 15- } \\
\text { bp deletion in exon } \\
\text { 19, 43B2 antibody } \\
\text { positive in (93\%) } \\
\text { patients with exon } 21 \\
\text { EGFR mutations with } \\
\text { L858R }\end{array}$ & $\begin{array}{l}\text { Simonetti S et al } \\
\text { J. Trans. Med/ } 2010^{26}\end{array}$ \\
\hline $\begin{array}{l}60 \mathrm{ADC} \text { and } \\
\text { cell lines }\end{array}$ & $\begin{array}{c}6 \mathrm{~B} 6 \text { and 43B2 } \\
\text { (Cell Signaling Technology, } \\
\text { Danvers, MA, USA) } \\
\text { Concentration: } 1: 100 \\
1 \text { mmol/L EDTA (pH 9.0) } \\
\text { target retrieval solution } \\
\text { (DakoCytomation) }\end{array}$ & $\begin{array}{l}0: \text { no staining, } 1+; \\
\text { weak, } 2+; \text { moderate, } \\
3+; \text { strong in }>10 \% \text { of } \\
\text { cancer cells. }\end{array}$ & DNA sequencing & $\begin{array}{c}6 \mathrm{~B} 6 \text { antibody: } \\
\text { Sensitivity } 79 \%, 43 \mathrm{~B} 2 \\
\text { antibody: Sensitivity } \\
83 \% .\end{array}$ & $\begin{array}{c}\text { Kawahara et al } \\
\text { Clinical cancer Res/ } \\
2010^{42}\end{array}$ \\
\hline $20 \mathrm{ADC}$ & $\begin{array}{c}6 \mathrm{~B} 6 \text { and } 43 \mathrm{~B} 2 \\
\text { (Cell Signaling Technology, } \\
\text { Danvers, MA, USA) } \\
\text { Concentration: 1:200 } \\
\text { Microwave boiling for } 10 \\
\text { minutes in } 1 \mathrm{mM} / 1 \text { EDTA }\end{array}$ & $\begin{array}{l}\text { Intensity graded as (+) } \\
\text { moderate to strong } \\
\text { staining, }( \pm) \text {, faint } \\
\text { staining, and }(-) \text {, no } \\
\text { staining. }\end{array}$ & $\begin{array}{l}\text { Peptide nucleic acid- } \\
\text { locked nucleic acid } \\
\text { polymerase chain } \\
\text { reaction clamp method } \\
\text { and DNA sequencing }\end{array}$ & $\begin{array}{l}90 \% \text { sensitivity and } \\
100 \% \text { specificity }\end{array}$ & $\begin{array}{c}\text { Nakamura H et al } \\
\text { Anticancer Res } / 2010^{28}\end{array}$ \\
\hline 154 ADC & $\begin{array}{c}6 \mathrm{~B} 6 \text { and 43B2 } \\
\text { (Cell Signaling Technology, } \\
\text { Danvers, MA, USA) } \\
\text { Concentration: } 1: 100 \\
\text { Microwave boiling for } 10 \\
\text { minutes in } 1 \mathrm{mM} / 1 \text { EDTA }\end{array}$ & $\begin{array}{l}0: \text { no staining, } 1+; \\
\text { weak, } 2+; \text { moderate, } \\
3+; \text { strong in }>10 \% \text { of } \\
\text { cancer cells. }\end{array}$ & Direct sequencing & $\begin{array}{l}746 \text { 750del (55\%)- } \\
\text { were positive with } \\
\text { the } 6 \mathrm{~B} 6 \text { antibody. } \\
\text { L858 }(24 \%) \text {-were } \\
\text { positive with the } 43 \mathrm{~B} 2 \\
\text { antibody. }\end{array}$ & $\begin{array}{c}\text { Hofman P et al } \\
\text { Ann Oncol/ } 2012^{29}\end{array}$ \\
\hline 399 ADC & $\begin{array}{c}6 \mathrm{~B} 6 \text { and 43B2 } \\
\text { (Cell Signaling Technology, } \\
\text { Danvers, MA, USA) } \\
\text { Concentration: } 1: 400 \\
1 \text { mmol/L EDTA (pH 9.0) } \\
\text { target retrieval solution } \\
\text { (DakoCytomation) }\end{array}$ & $\begin{array}{l}0: \text { no staining, } 1+; \\
\text { weak, } 2+; \text { moderate, } \\
3+; \text { strong in }>10 \% \text { of } \\
\text { cancer cells. }\end{array}$ & Taqman PCR & $\begin{array}{l}\text { Specificity and PPV } \\
\text { 100\% with score } 3+, \\
\text { PPV 93\% with score 0, } \\
\text { scores } 1+\text { and } 2+\text { are } \\
\text { unreliable. }\end{array}$ & $\begin{array}{c}\text { Jiang G et al } \\
\text { Plos One/ } 2013^{30}\end{array}$ \\
\hline $247 \mathrm{ADC}$ & $\begin{array}{c}\text { 6B6/43B2 (Cell Signaling } \\
\text { Technology, Danvers, MA, } \\
\text { USA.) concentration: 1:30 } \\
\text { SP111/SP125 (Pre-dilute) } \\
\text { (Ventana Medical Systems, } \\
\text { Tucson, AZ, USA.) }\end{array}$ & $\begin{array}{l}0: \text { no staining, } 1+; \\
\text { weak, } 2+; \text { moderate, } \\
3+; \text { strong in }>10 \% \text { of } \\
\text { cancer cells. }\end{array}$ & $\begin{array}{c}\text { Mass spectrometry, } \\
\text { fragment analysis and } \\
\text { direct PCR sequencing } \\
\text { platforms }\end{array}$ & $\begin{array}{l}\text { SP125: Sensitivity } \\
\text { 76\%, PPV 73\%, 43B2: } \\
\text { Sensitivity 62\%, } \\
\text { PPV } 87 \% . \text { SP111: } \\
\text { Sensitivity: 83\%, PPV } \\
\text { 94\%. 6B6: Sensitivity } \\
\text { 89\% and PPV 76\% }\end{array}$ & $\begin{array}{l}\text { Allo G ET AL } \\
\text { Histopathology/2014 }\end{array}$ \\
\hline 210 NSCLC & $\begin{array}{c}\text { 6B6 and 43B2 } \\
\text { (Cell Signaling Technology, } \\
\text { Danvers, MA, USA) } \\
\text { Concentration: } 1: 150\end{array}$ & H-score & RT-PCR & $\begin{array}{c}\text { 6B6: Specificity } 98.8 \% \\
\text { 43B2 specificity } 97.8 \% \\
\text { 6B6 Sensitivity } 63.2 \% \\
\text { 43B2 } 80.0 \%\end{array}$ & $\begin{array}{c}\text { Bondgaard ET AL } \\
\text { Modern pathology/ } \\
2014^{34}\end{array}$ \\
\hline 154 ADC & $\begin{array}{c}\text { SP111 and SP125 (Pre- } \\
\text { dilute) } \\
\text { (Ventana Medical Systems, } \\
\text { Tucson, AZ, USA.) }\end{array}$ & $\begin{array}{l}0: \text { no staining, } 1+; \\
\text { weak, } 2+; \text { moderate, } \\
3+\text {; strong in }>10 \% \text { of } \\
\text { cancer cells. }\end{array}$ & DNA sequencing & $\begin{array}{c}\text { Sensitivity } 75.6 \% \text {, } \\
\text { specificity } 94.5 \% \text { PPV } \\
85 \% \text { and NPV } 90.4 \%\end{array}$ & $\begin{array}{c}\text { Kim CH et al } \\
\text { Cancer Res Treat/ } \\
2015^{23}\end{array}$ \\
\hline
\end{tabular}




\begin{tabular}{|c|c|c|c|c|c|}
\hline 206 ADC & $\begin{array}{c}6 \mathrm{~B} 6 \text { and 43B2 } \\
\text { (Cell Signaling Technology, } \\
\text { Danvers, MA, USA) } \\
\text { Concentration: } 1: 100 \\
\text { Citric acid pH } 6.0\end{array}$ & $\begin{array}{l}0: \text { no staining, } 1+; \\
\text { weak, } 2+; \text { moderate, } \\
3+\text {; strong in }>10 \% \text { of } \\
\text { cancer cells. }\end{array}$ & $\begin{array}{l}\text { High resolution } \\
\text { melting analysis, } \\
\text { DNA sequencing and } \\
\text { fragment analysis }\end{array}$ & $\begin{array}{c}\text { Concordance } 85.7 \% \text {. } \\
\text { 43B2 sensitivity was } \\
\text { 60\%, specificity } 100 \% \text {, } \\
\text { PPV } 100 \% \text { and NPV } \\
84.6 \% .6 \mathrm{~B} 6 \text { antibody } \\
\text { sensitivity, specificity, } \\
\text { PPV and NPV } \\
\text { were } 100 \%\end{array}$ & $\begin{array}{c}\text { Jain D et al } \\
\text { Indian J Med Res/ } \\
2016^{32}\end{array}$ \\
\hline $\begin{array}{l}43 \text { lung AIS, } \\
\text { and MIA }\end{array}$ & $\begin{array}{c}6 \mathrm{~B} 6 \text { and 43B2 } \\
\text { (Cell Signaling Technology, } \\
\text { Danvers, MA, USA) } \\
\text { Concentration: } 1: 200 \\
\text { Microwave boiling for } 10 \\
\text { minutes in } 1 \mathrm{mM} / 1 \text { EDTA }\end{array}$ & $\begin{array}{l}\text { Intensity graded as (+) } \\
\text { moderate to strong } \\
\text { staining, }( \pm) \text {, faint } \\
\text { staining, and }(-) \text {, no } \\
\text { staining. }\end{array}$ & $\begin{array}{l}\text { Peptide nucleic acid- } \\
\text { locked nucleic acid } \\
\text { polymerase chain } \\
\text { reaction clamp method } \\
\text { and DNA sequencing }\end{array}$ & $\begin{array}{c}\text { Concordance } 88.4 \% \text {. } \\
\text { DNA analysis in AIS } \\
\text { was } 27.3 \% \text { and in MIA } \\
\text { was } 42.9 \% \text { while IHC } \\
\text { in AIS was } 22.7 \% \text { and } \\
\text { in MIA was } 42.9 \% \\
\end{array}$ & $\begin{array}{l}\text { Nakamura } \mathrm{H} \text { et al } \\
\text { Lung cancer/ } 2016^{27}\end{array}$ \\
\hline 216 ADC & $\begin{array}{c}6 \mathrm{~B} 6 \text { and } 43 \mathrm{~B} 2 \\
\text { (Cell Signaling Technology, } \\
\text { Danvers, MA, USA) } \\
\text { Concentration: } 1: 100 \\
\text { Tris EDTA pH9 boiling in } \\
\text { steamer for } 30 \text { minutes }\end{array}$ & $\begin{array}{c}0: \text { no staining, } 1+; \\
\text { weak, } 2+; \text { moderate, } \\
3+; \text { strong in }>10 \% \\
\text { of cancer cells and } \\
\text { H-score }\end{array}$ & DNA sequencing & Concordance $90 \%$ & $\begin{array}{l}\text { Gaber R et al } \\
\text { RJME/ } 2017^{33}\end{array}$ \\
\hline
\end{tabular}

Abbreviations: ADC; adenocarcinoma, Conc; concentration, N; number, NSCLC; non-small cell carcinoma, PPV; positive predictive value, NPV; negative predictive value

number and showed a significant statistical association between both parameters ${ }^{3}$.

Other studies have investigated the relation between EGFR copy number and EGFR mutation. Wang et al study included 502 TKI-treated advanced NSCLC cases. Gene copy number was analyzed by FISH using the Colorado scoring system while EGFR mutation was detected using the Surplex EGFR mutation Kit (Surexam Bio-Tech, Guangzhou, China). The combined analysis of EGFR FISH and mutation showed higher response rates with better progression free survival and overall survival in cases with EGFR positive FISH and EGFR mutations in response to TKIs ${ }^{40}$.

On the other hand, Sholl et al, investigated 40 NSCLC specimens with sequence analysis, IHC for wild-type EGFR, FISH and chromogenic in situ hybridization (CISH). They concluded that EGFR sequence analysis was the only useful method for predicting response and progression free survival following TKI therapy in NSCLC ${ }^{41}$.

\section{Conclusions}

The presence of EGFR mutations, gene copy number gains, and overexpression of wild-type EGFR is a triad of biomarkers known to predict responsiveness to TKIs. Efficient prediction depends ultimately on the accuracy and robustness of the methods used to measure the biomarkers predicting responses to therapy. IHC using mutationspecific antibodies is a simple and inexpensive technique, but standardization of the assay procedure and of the scoring system is important to obtain reproducible and reliable results. Reliable IHC results with high concordance to gold standard molecular genetic techniques have been demonstrated in many studies of lung ADC. Some studies showed that although the specificity of both antibodies is high, the sensitivity of the 6B6 antibody was low compared to the molecular techniques except for E746_A750 mutation detection ${ }^{34,35}$. Taking into consideration that the 6B6 antibody was generated to detect specifically the 15bp deletion E746-A750, other antibodies are needed to be developed for more sensitive and specific detection of other types of mutation. Furthermore, the interplay between EGFR mutation, gene copy number and overexpression and their importance to predict TKIs response, is an indication for the importance of the analysis of the three EGFR parameters.

\section{References}

1. Arora A, Scholar EM. Role of tyrosine kinase inhibitors in cancer therapy. The Journal of pharmacology and experimental therapeutics. $2005 ; 315(3): 971-9$.

2. Ono M, Kuwano M. Molecular mechanisms of epidermal growth factor receptor (EGFR) activation and response to gefitinib and other EGFRtargeting drugs. Clinical cancer research : an official journal of the American Association for Cancer Research. 2006; 12(24): 7242-51.

3. Gaber R, Watermann I, Kugler C, et al. Correlation of EGFR expression, gene copy number and clinicopathological status in NSCLC. Diagnostic pathology. 2014; 9: 165.

4. Li AR, Chitale D, Riely GJ, et al. EGFR mutations in lung adenocarcinomas: clinical testing experience and relationship to EGFR gene copy number and immunohistochemical expression. The Journal of molecular diagnostics : JMD. 2008; 10(3): 242-8.

5. Ladanyi M, Pao W. Lung adenocarcinoma: guiding EGFR-targeted therapy and beyond. Modern pathology : an official journal of the United States and Canadian Academy of Pathology, Inc. 2008; 21 Suppl 2: S16-22.

6. Lynch TJ, Bell DW, Sordella R, et al. Activating mutations in the epidermal growth factor receptor underlying responsiveness of non-small-cell lung cancer to gefitinib. N Engl J Med. 2004; 350(21): 2129-39. 
7. Cappuzzo F, Ligorio C, Janne PA, et al. Prospective study of gefitinib in epidermal growth factor receptor fluorescence in situ hybridizationpositive/phospho-Akt-positive or never smoker patients with advanced non-small-cell lung cancer: the ONCOBELL trial. Journal of clinical oncology : official journal of the American Society of Clinical Oncology. 2007; 25(16): 2248-55.

8. Paez JG, Janne PA, Lee JC, et al. EGFR mutations in lung cancer: Correlation with clinical response to gefitinib therapy. Science. 2004; 304(5676): 1497-500.

9. Pao W, Miller V, Zakowski M, et al. EGF receptor gene mutations are common in lung cancers from "never smokers" and are associated with sensitivity of tumors to gefitinib and erlotinib. Proc Natl Acad Sci U S A. 2004; 101(36): 13306-11.

10. Riely GJ, Pao W, Pham D, et al. Clinical course of patients with nonsmall cell lung cancer and epidermal growth factor receptor exon 19 and exon 21 mutations treated with gefitinib or erlotinib. Clinical cancer research : an official journal of the American Association for Cancer Research. 2006; 12(3 Pt 1): 839-44.

11. Kato Y, Peled N, Wynes MW, et al. Novel epidermal growth factor receptor mutation-specific antibodies for non-small cell lung cancer: immunohistochemistry as a possible screening method for epidermal growth factor receptor mutations. Journal of thoracic oncology : official publication of the International Association for the Study of Lung Cancer. 2010; 5(10): 1551-8.

12. Engelman JA, Mukohara T, Zejnullahu K, et al. Allelic dilution obscures detection of a biologically significant resistance mutation in EGFRamplified lung cancer. J Clin Invest. 2006; 116(10): 2695-706.

13. Kimura H, Kasahara K, Kawaishi M, et al. Detection of epidermal growth factor receptor mutations in serum as a predictor of the response to gefitinib in patients with non-small-cell lung cancer. Clinical cancer research : an official journal of the American Association for Cancer Research. 2006; 12(13): 3915-21.

14. Wittwer CT, Reed GH, Gundry CN, et al. High-resolution genotyping by amplicon melting analysis using LCGreen. Clinical chemistry. 2003; 49(6 Pt 1): 853-60.

15. Little S. Amplification-refractory mutation system (ARMS) analysis of point mutations. Current protocols in human genetics. 2001; Chapter 9: Unit 9.8

16. Thelwell N, Millington S, Solinas A, et al. Mode of action and application of Scorpion primers to mutation detection. Nucleic acids research. 2000; 28(19): 3752-61.

17. Nakamura H, Koizumi H, Sakai H, et al. Accuracy of the cobas EGFR Mutation Assay in Non-small-cell Lung Cancer Compared With Three Laboratory-developed Tests. Clinical lung cancer. 2018; 19(2): 170-4.

18. Kazandjian D, Blumenthal GM, Yuan W, et al. FDA Approval of Gefitinib for the Treatment of Patients with Metastatic EGFR Mutation-Positive Non-Small Cell Lung Cancer. Clinical cancer research : an official journal of the American Association for Cancer Research. 2016 22(6): 1307-12.

19. Penzel R, Sers C, Chen Y, et al. EGFR mutation detection in NSCLC-assessment of diagnostic application and recommendations of the German Panel for Mutation Testing in NSCLC. Virchows Archiv : an international journal of pathology. 2011; 458(1): 95-8.

20. Ellison G, Zhu G, Moulis A, et al. EGFR mutation testing in lung cancer: a review of available methods and their use for analysis of tumour tissue and cytology samples. Journal of clinical pathology. 2013; 66(2): 79-89.

21. Yu J, Kane S, Wu J, et al. Mutation-specific antibodies for the detection of EGFR mutations in non-small-cell lung cancer. Clinical cancer research : an official journal of the American Association for Cancer Research. 2009; 15(9): 3023-8.

22. Yoshida M, Nagatomo T, Ohnishi T, et al. Detection of epidermal growth factor receptor mutations in lung adenocarcinoma cytological specimens by immunocytochemistry. Molecular and clinical oncology. 2017; 7(6): 981-7.

23. Kim CH, Kim SH, Park SY, et al. Identification of EGFR Mutations by Immunohistochemistry with EGFR Mutation-Specific Antibodies in Biopsy and Resection Specimens from Pulmonary Adenocarcinoma. Cancer research and treatment : official journal of Korean Cancer Association. 2015; 47(4): 653-60.

24. Watanabe K, Fukuhara T, Tsukita Y, et al. EGFR Mutation Analysis of Circulating Tumor DNA Using an Improved PNA-LNA PCR Clamp Method. Canadian respiratory journal. 2016; 2016: 5297329.

25. Brevet M, Arcila M, Ladanyi M. Assessment of EGFR mutation status in lung adenocarcinoma by immunohistochemistry using antibodies specific to the two major forms of mutant EGFR. The Journal of molecular diagnostics : JMD. 2010; 12(2): 169-76.

26. Simonetti S, Molina MA, Queralt C, et al. Detection of EGFR mutations with mutation-specific antibodies in stage IV non-small-cell lung cancer. Journal of translational medicine. 2010; 8: 135.

27. Nakamura H, Koizumi H, Kimura H, et al. Epidermal growth factor receptor mutations in adenocarcinoma in situ and minimally invasive adenocarcinoma detected using mutation-specific monoclonal antibodies. Lung Cancer. 2016; 99: 143-7.

28. Nakamura H, Mochizuki A, Shinmyo T, et al. Immunohistochemical detection of mutated epidermal growth factor receptors in pulmonary adenocarcinoma. Anticancer research. 2010; 30(12): 5233-7.

29. Hofman P, Ilie M, Hofman V, et al. Immunohistochemistry to identify EGFR mutations or ALK rearrangements in patients with lung adenocarcinoma. Ann Oncol. 2012; 23(7): 1738-43.

30. Jiang G, Fan C, Zhang X, et al. Ascertaining an appropriate diagnostic algorithm using EGFR mutation-specific antibodies to detect EGFR status in non-small-cell lung cancer. PLoS One. 2013; 8(3): e59183.

31. Allo G, Bandarchi B, Yanagawa N, et al. Epidermal growth factor receptor mutation-specific immunohistochemical antibodies in lung adenocarcinoma. Histopathology. 2014; 64(6): 826-39.

32. Jain D, Iqbal S, Walia R, et al. Evaluation of epidermal growth factor receptor mutations based on mutation-specific immunohistochemistry in non-small cell lung cancer: A preliminary study. The Indian journal of medical research. 2016; 143(3): 308-14.

33. Gaber R, Watermann I, Kugler C, et al. Pre-selection of EGFR mutations in non-small-cell lung cancer patients by immunohistochemistry: comparison with DNA-sequencing, EGFR wild-type expression, gene copy number gain and clinicopathological data. Romanian journal of morphology and embryology = Revue roumaine de morphologie et embryologie. 2017; 58(4): 1175-84.

34. Bondgaard AL, Hogdall E, Mellemgaard A, et al. High specificity but low sensitivity of mutation-specific antibodies against EGFR mutations in non-small-cell lung cancer. Modern pathology : an official journal of the United States and Canadian Academy of Pathology, Inc. 2014; 27(12): 1590-8.

35. Seo AN, Park TI, Jin Y, et al. Novel EGFR mutation-specific antibodies for lung adenocarcinoma: highly specific but not sensitive detection of an E746_A750 deletion in exon 19 and an L858R mutation in exon 21 by immunohistochemistry. Lung Cancer. 2014; 83(3): 316-23.

36. Tsuchihashi Z, Khambata-Ford S, Hanna N, et al. Responsiveness to cetuximab without mutations in EGFR. N Engl J Med. 2005; 353(2): 208-9.

37. Hirsch FR, Varella-Garcia M, Cappuzzo F, et al. Combination of EGFR gene copy number and protein expression predicts outcome for advanced non-small-cell lung cancer patients treated with gefitinib. Ann Oncol. 2007; 18(4): 752-60.

38. Cappuzzo F, Hirsch FR, Rossi E, et al. Epidermal growth factor receptor 
gene and protein and gefitinib sensitivity in non-small-cell lung cancer. Journal of the National Cancer Institute. 2005; 97(9): 643-55.

39. Zlobec I, Raineri I, Schneider S, et al. Assessment of mean EGFR gene copy number is a highly reproducible method for evaluating FISH in histological and cytological cancer specimens. Lung Cancer. 2010; 68(2): 192-7.

40. Wang F, Fu S, Shao Q, et al. High EGFR copy number predicts benefits from tyrosine kinase inhibitor treatment for non-small cell lung cancer patients with wild-type EGFR. Journal of translational medicine. 2013; 11: 90.
41. Sholl LM, Xiao Y, Joshi V, et al. EGFR mutation is a better predictor of response to tyrosine kinase inhibitors in non-small cell lung carcinoma than FISH, CISH, and immunohistochemistry. Am J Clin Pathol. 2010; 133(6): 922-34.

42. Kawahara A, Yamamoto C, Nakashima K, et al. Molecular diagnosis of activating EGFR mutations in non-small cell lung cancer using mutation-specific antibodies for immunohistochemical analysis. Clinical cancer research : an official journal of the American Association for Cancer Research. 2010; 16(12): 3163-70. 